\title{
The Witches and the Witch: Verdi's Macbeth
}

\section{Citation}

Albright, Daniel. 2005. The witches and the witch: Verdi's Macbeth. Cambridge Opera Journal 17(3): 225-252.

\section{Published Version}

http://dx.doi.org/10.1017/S0954586706002059

\section{Permanent link}

http://nrs.harvard.edu/urn-3:HUL.InstRepos:2623546

\section{Terms of Use}

This article was downloaded from Harvard University's DASH repository, and is made available under the terms and conditions applicable to Other Posted Material, as set forth at http:// nrs.harvard.edu/urn-3:HUL.InstRepos:dash.current.terms-of-use\#LAA

\section{Share Your Story}

The Harvard community has made this article openly available.

Please share how this access benefits you. Submit a story.

\section{Accessibility}




\title{
The witches and the witch: Verdi's Macbeth
}

\author{
DANIEL ALBRIGHT
}

\begin{abstract}
The witches in Shakespeare's Macbeth equivocate between the demons of random malevolence and ordinary (if exceptionally nasty) old women; and both King James I, whose book on witchcraft may have influenced Shakespeare, and A. W. Schlegel, whose essay on Macbeth certainly influenced Verdi, also stress this ambiguity. In his treatment of Lady Macbeth, Verdi uses certain musical patterns associated with the witches; and like the witches, who sound sometimes tame and frivolous, sometimes like incarnations of supernatural evil, Lady Macbeth hovers insecurely between roles: she is a hybrid of ambitious wife and agent of hell.
\end{abstract}

\section{Macbeth as Saturday Night Live}

Part of the power of Shakespeare's tragedies lies in their goofiness. Shakespeare often seems to begin with some premise straight out of an actors' workshop, some casual improvisatory game, and then to erect some magnificent structure of rhetoric upon a foundation of sand - or no foundation at all. When I was a boy I often attended a comedy club in Chicago called Second City, in which the actors asked the audience to call out suggestions for a skit ('Peeling an apple with a chainsaw!' 'An astronaut in a spacesuit peeling an apple with a chainsaw!'). The premise of Macbeth seems devised in just this manner ('The forest marches up to the castle!' 'The forest marches up to the castle and kills the king!'). For their private amusement, the witches keep calling out new roles and new situations, and Macbeth struggles as best he can to comply:

1. Witch. All hail, Macbeth, hail to thee, Thane of Glamis!

2. Witch. All hail, Macbeth, hail to thee, Thane of Cawdor!

3. Witch. All hail, Macbeth, that shall be King hereafter! (1.3.48-50)

In an improvised comedy, Macbeth would run around the stage, first scowling like the Thane of Cawdor, at last crowning himself with a horseshoe and holding up his riding-stick as a sceptre. Of course, Macbeth is a comedy only from the witches' point of view, and the tragic actors must maintain a certain decorum. But it is necessarily a short distance from Macbeth addressing a non-existent dagger to Marlon Brando pretending to melt, in Lee Strasberg's studio. The cast of Shakespeare's play is a gang of actors trying, with whatever technical virtuosity they can muster, to cope with the fiendish demands of a final examination in the witches' drama school.

Because Shakespeare so completely assimilated the absurdities of the plot into a pseudo-rational structure, and because the tone of the play is so dark, it is easy to forget just how outrageous, how hilarious it all is. But if the witches in Macbeth were continuously present at the margins of the stage, like Christopher Sly in many productions of The Taming of the Shrew, the director would have to show them growing more and more giddy with delight. We can't entirely sympathise with their glee, for we're human beings, too implicated in the drama of guilt and slaughter 
elaborated on the stage; but it's possible to respect the witches as pure aesthetes, connoisseurs of theatre, contriving a spectacle in which an actor has to play a brave and loyal nobleman, a henpecked husband, an assassin, a wicked king - roles that have nothing to do with one another, as if plucked from a deck of cards - before he's made to confess, in his last soliloquy, that he's just a 'poor player / That struts and frets his hour upon the stage' (5.5.24-5). This is improvisatory comedy for a nightclub in hell.

The disorder within the character of Macbeth - if the term 'character' can be applied to someone so fundamentally lacking in a fixed identity - is only one of the many disorders that Shakespeare examines in this play. Indeed Macbeth is a study in randomness, as Shakespeare's age understood it; and the essential power of randomising lies in the domain of the witches. In this article I will first sketch something of the nature of witches, as Shakespeare and Shakespeare's commentators understood them, and then suggest some ways in which Verdi deranged some of the conventions of Italian opera in order to accommodate Macbeth's general witchiness, as seen not only in the witches themselves but also in their odd way of assimilating Lady Macbeth into their coven.

\section{Demonology}

It is generally thought that Shakespeare wrote Macbeth around 1606, to celebrate the accession, after the death of Queen Elizabeth in 1603, of King James VI of Scotland to the throne of England, as King James I. James prided himself on his scholarship, particularly on witchcraft, the subject of his 1597 book, Daemonologie. He undertook this study as part of the debate concerning the reality of witches - a debate in which he had the unusual advantage (as Stephen Greenblatt has noted) of being able to order the burning of books that doubted the existence of witches, such as Reginald Scot's The Discoverie of Witchcraft. ${ }^{1}$ Of course, on stage everything is real unless we are specifically told otherwise; but King James, at a performance of Macbeth, would have been a spectator quite inclined to accept that witches are real women who work supernatural harm.

What, exactly, is a witch? Why would someone wish to become one? King James asks this very question, and answers it as follows: 'Curiositie in great ingines: thirst of revenge, for some tortes deeply apprehended: or greedie appetite of geare, caused through great pouerty. As to the first of these, Curiosity, it is onelie the inticement of Magiciens, or Necromanciers: and the other two are the allureres of the Sorcerers, or Witches.'2 Witches, then, are commonplace impoverished old women so greedy and vengeful that they make a bargain with Satan to get what they want. Shakespeare's witches, however, seem poised between two constructions: either they are disgusting old women with a taste for malice (as King James presents all witches); or they are evil incarnate, multiple Satans in drag - Macbeth is disturbed to see that they have beards (1.3.46).

${ }^{1}$ Stephen Greenblatt, 'Shakespeare Bewitched', in New Historical Literary Study, ed. Jeffrey N.

Cox and Larry J. Reynolds (Princeton, 1993), 118.

${ }^{2}$ King James, Daemonologie (Edinburgh, 1966), 8. 
The power of witches in fact springs from their ambiguity, their appetite for scattering things about. In defining the word 'witchcraft' James claimed that it was simply the English equivalent of the Latin word 'sorcery', 'which is taken from the casting of the lot.... The cause wherefore [sorcerers] were called sortiarij, proceeded of their practicques seeming to come of lot or chance: Such as the turning of the riddle'. ' (A 'riddle' in this sense is a coarse sieve used for separating grain from chaff, or sand from gravel; 'turning the riddle' is a method of divination, especially useful for identifying thieves.) The theory of sorcery, then, is that chance patterns, such as the distribution of small objects that have passed through a sieve, or the array of tea-leaves at the bottom of a cup, can be construed as manifestations of hidden wisdom. How can we know the future? - by studying the shapes that arise in shapeless things, plastic to the subtle pressures of foreknowledge. The more randomness, then, the greater the possibility of revelation. Shakespeare's experiment in Macbeth is to test the theory of sorcery by constructing a whole theatrical world of ambiguity, equivocation, fog, night, to see whether chance operations can generate shapes more meaningful, more portentous, than the normal operations of reason and imagination.

There is sorcery everywhere in Shakespeare's mature tragedies; Macbeth is unusual only in that it makes explicit the general principle of divination by chance patterns. Hamlet, for example, plays sorcerer with Polonius, when he asks the old courtier 'Do you see yonder cloud that's almost in the shape of a camel?' (3.2.376-7); the deferential Polonius sees that it indeed resembles a camel. But, when Hamlet proposes that the cloud might look more like a weasel, Polonius agrees - and further agrees that it is very like a whale. Polonius fails Hamlet's test: for Polonius, a shapelessness is just a shapelessness, without any capacity to turn itself into an omen; for Hamlet, however, rough-hewn forms imply a shaping force (5.2.10). When Hamlet sees an inkblot, such as the players' silly skit about Pyrrhus and Priam, he can read in it the outlines of his own hopes and terrors. Perhaps the most daring feature of Shakespeare's art is his willingness to traffic with the bulging, the deformed, the ostentatiously trivial; every attempt to cut his plays by removing extraneous matter tends to hamstring their operation, for the mature tragedies operate by illustrating a mind trying to cope with the general extraneousness of things.

The witches in Macbeth are character-clouds, personages that can be construed in any number of different ways. As Stephen Greenblatt points out, the witches 'account for nothing ... it is in fact extremely difficult to specify what, if anything, they do or even what, if anything, they are'. ${ }^{4}$ Their function is simply to open up areas of empty space, in which vagrant ugly desires can manifest themselves, in which deeds without names (4.1.49) can take place. Theirs is not the moving finger that writes down all that will come to pass; they simply provide a blank tablet that the human characters figure with obscene scrawls.

${ }^{3}$ King James, Daemonologie, 31.

${ }^{4}$ Stephen Greenblatt, 'Shakespeare Bewitched', 122-3. 


\section{Witch evolution}

The stage history of Macbeth is a horror story in which the role of the witches keeps expanding, and frantic attempts are made to restrain their magic power. Even by the time of Macbeth's first publication, in the First Folio of 1623 (seven years after Shakespeare's death), someone seems to have spliced into Shakespeare's text a new witch, or witchmaster, Hecate (3.5 and 4.1.39-43). In both her scenes Hecate is associated with music: the stage directions instruct the witches to perform songs, 'Come away' at the end of 3.5, and 'Black spirits' at 4.1.43. The Folio doesn't give the text of either song, but each can be found both in Thomas Middleton's The Witch (c. 1609) and in the Davenant version of Macbeth (1663-4, publ. 1674). It is possible that the Hecate scenes and songs are the work of Middleton; in any case they greatly distend the spatial range of the witches. Hecate, above all, loves to fly:

I am for th' air; this night I'll spend

Unto a dismal and a fatal end.

Great business must be wrought ere noon:

Upon the corner of the moon

There hangs a vap'rous drop profound,

I'll catch it ere it come to ground ... (3.5.20-5)

[Hecate] Hark, I am call'd, my little Spirit see,

Sits in a foggy Cloud, and stays for me. [Macbine descends

Sing within.... $3[$ rd spirit]. $\mathrm{O}$ what a dainty pleasure's this,

To sail i'th' Air while the Moon shines fair;

To sing, to Toy, to Dance and Kiss,

Over Woods, high Rocks and Mountains;

Over Hills, and misty Fountains:

Over Steeples, Towers, and Turrets:

We flye by night 'mongst troops of Spirits.

No Ring of Bells to our Ears sounds,

No howles of Wolves, nor Yelps of Hounds;

No, nor the noise of Waters breach,

Nor Cannons Throats our Height can reach. ${ }^{5}$

The authentically Shakespearean witches were also capable of rapid movement to distant places - one of them sails in a sieve to Aleppo to waste a stingy woman's husband. But Hecate and her minions seem more exhilarated by the flying itself than by any mischief to be done at the destination. There is a childlike erotic quality to these scenes, as the spirits dream of tumbling with one another, toying and kissing in a realm without gravity; they seem to be less witches than putti, exulting in their immunity from pain, their capacity for vertigo, their freedom of topsy-turvy, roll, pitch, yaw.

These quotations illustrate how the witches evolve: Shakespeare's witches are focused, task-orientated creatures, confecting spectacles for the sake of their effect

${ }^{5}$ Davenant, Macbeth 3.8, quoted in The Riverside Shakespeare, ed. G. Blakemore Evans (Boston, 1974), 1341; this is the edition used for Shakespeare quotations. 

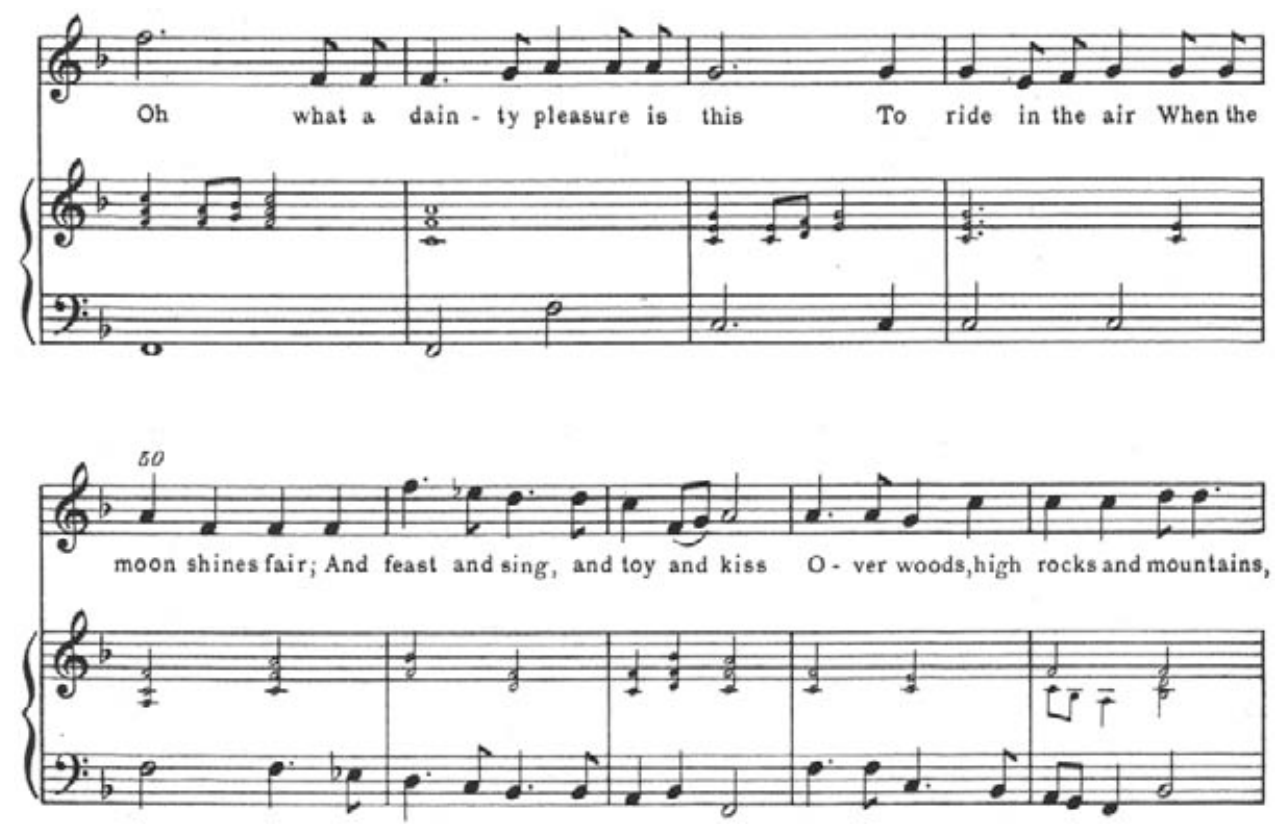

Ex. 1: Robert Johnson, 'Come away, Hecate'

on Macbeth; they are strictly local parcae. Like the doorkeeper in Kafka's parable 'Before the Law' (1914) who guards a doorway into the Law devised for one man and one man only, the witches seem to be dedicated to Macbeth alone. When they succeed in destroying him, they vanish; their peculiar sort of evil seems no longer to exist as a factor in human affairs. They dispel themselves as they finish casting spells on Macbeth. Hecate, on the other hand, is a spirit of zigzag self-delight, with a short attention span, lavish with her prodigies; she's self-consciously impressive, but her malice is so theoretical that she seems innocuous, cartoonish. Shakespeare's witches have a boniness, a deformity, a rancour - they aren't far from the actual old crones who, in King James's account, bartered with the devil for supernatural power. But Hecate and her crew are aerial images, the giddy components of a magic show. The poetry of Shakespeare's witches is full of low icky things, adder's tongue and goat's gall. But the Hecate poetry is lyrical and lithe - such lines as 'To sail i'th' Air while the Moon shines fair' could be part of the popular music of any age. Robert Johnson (b. 1582), who wrote the music for two Ariel songs in The Tempest, composed a setting of 'Come away'; the passage from 'To sail i'th' Air while the Moon shines fair' to the end is lilting, jingly, a clear crowd-pleaser (Ex. 1).

It seems that even in the 1610s Macbeth was beginning to move towards opera. The witches not only want to fly, but also want to sing; they need to push the play into the dimension of music theatre, just as they sail through the unroofed theatre building to the height of the moon. It is the witches who motivate the opera lurking near the surface of the drama.

The performance history of Macbeth is marked by two themes: first, its rapid accumulation of a corpus of incidental music - of all Shakespeare's tragedies, 
Macbeth was the most musical, despite its lack of explicit singing in the manner of Ophelia or the gravediggers in Hamlet. The second large theme in Macbeth's evolution is the expansion of the witches' authority, not only on stage (as more lines and more elaborate stage machinery were added to their parts), but also backstage (as the play became an object of actors' superstitions, its very name so taboo that an actor who spoke the title out loud needed to perform certain rituals of pacing and throwing salt in order to avoid bad luck), and finally in the domain of literary criticism.

Loosed among literary critics, the witches accomplished terrible things.

The most vexing problem the witches presented was their destabilising of such terms as 'realistic' and 'fantastic', or 'fatal' and 'trivial'. They impinge on the most august realms of the moral universe, and seem intimate with Necessity itself, and yet slime clings to them. The theatre traditionally represents a condition where human deviance is corrected by the imposition of some secret order; but Macbeth, like Job, presents a more disturbing picture of human rectitude ruined by some transcendental taste for the vicious. The play demonstrates, in good tragic fashion, that vice is self-limiting and self-terminating, but it seems clear that Scotland is the victim, not of merely human depravity, but of the depravity of histrionic gods (like those of Lucretius) who rejoice at the spectacle of our lives as a kind of snuff play. Macbeth is intolerable, not because it suggests that human life is a tragedy, but that it is a tragedy of a peculiarly low-grade, contemptible sort - a B-movie horror squealer, with cheap special effects. In Greek tragedy, fate shows a real refinement of sensibility; here, by contrast, fate seems bored and childish, capable of stimulating itself only through a brisk game of Mortal Kombat. The mood of Macbeth is similar to that of Forster's A Passage to India (1924): 'Visions are supposed to entail profundity, but_— Wait till you get one, dear reader! The abyss also may be petty, the serpent of eternity made of maggots'. ${ }^{6}$

The older literary critics were fascinated by the witches' bizarre combination of the gross and the sublime. How could a witch manage to be a hag and an avatar of ultimate evil at the same time? Some critics thought that consistency demanded that one aspect must be sacrificed; Coleridge, for example, insisted on deleting every Halloweenery from their appearance, and elevating them to the stature of Parcae or Erinyes, as a report of an unpublished lecture of 1813 suggests:

Mr. Coleridge began by commenting on the vulgar stage error which transformed the Weird Sisters into witches with broomsticks. They were awful beings, and blended in themselves the Fates and Furies of the ancients with the sorceresses of Gothic and popular superstitions. They were mysterious natures: fatherless, motherless, sexless: they come and disappear: they lead evil minds from evil to evil, and have the power of tempting those who have been the tempters of themselves. The exquisite judgment of Shakespeare is shown in nothing more than in the different language of the Witches with each other, and with those whom they address: the former displays a certain fierce familiarity, grotesqueness mingled with terror; the latter is always solemn, dark, mysterious. ${ }^{7}$

${ }^{6}$ E. M. Forster, A Passage to India (New York, 1952), 208.

7 Frank Kermode, Four Centuries of Shakespearean Criticism (New York, 1965), 536-7. 
Though Coleridge would like to denature and metaphysicise the witches, dignify them, he is deeply conscious of their divided nature: part Gothic, part Greek-tragic; part ugly gossip, part will towards annihilation. But he refuses another possibility for understanding their twiformed character: the possibility that they might be at once vile and silly, a clown-show in Satan's circus. Even Coleridge's mind, finely tolerant of paradox, can't quite embrace the notion of a purely frivolous sort of damnation. But perhaps Shakespeare could: he may have found congenial the notion of hell as a kind of theatre, in which complete inauthenticity, absence of valid being, represented itself as a continual exchange of masks, a retouching of facelessness with make-up. No preacher against the sinfulness of the stage possessed the anti-theatrical prejudice quite so fully as Shakespeare himself.

It is intriguing that Coleridge emphasised the divided character of the witches' discourse, their habit of using one tonality among themselves and another in public, because it is just here where the witches' staginess is most clearly felt. They have a backstage rhetoric (actors' shoptalk and tale-telling) and an onstage rhetoric (the spiel of flesh-creep) - one reason why Hecate is a somewhat unwelcome addition to the text (in 3.5) in that she confuses these two areas, by suggesting that even backstage the witches are such compulsive showmen that they can't stop conjuring impressive spectacles, even when there's no Macbeth to impress. Shakespeare, on the other hand, knew that spectacles were expensive, and imagined a much more parsimonious sort of evil.

Another critic of Macbeth, even subtler than Coleridge, also stressed the strange split between the private witches and the public witches. This was Shakespeare's German translator, August Wilhelm Schlegel, who wrote in 1808:

The accumulation of rhymes, and the rhythms of the verse [in the witches' incantations], form, as it were, the hollow music of the nocturnal dances of these tenebrous beings. [Shakespeare] has been abused for using the names of disgusting objects; but who has ever imagined that the magic kettle of the witches was filled with agreeable aromatics? That would be kin, as the poet says, to desiring that hell should give good counsel. These repulsive things, from which the imagination shrinks, are here emblems of the hostile powers which ferment in nature's breast; and the repugnance of our sense is outweighed by the mental horror. With one another the witches discourse like women of the very lowest class [aus dem Pöbel] ... when, however, they address Macbeth they assume a loftier tone: their predictions ... have all the obscure brevity, the majestic solemnity of oracles, such as have ever spread terror among mortals.... It seems that the Destiny [Verbängnis] of the ancients rules again in the tragedy. ${ }^{8}$

Schlegel felt acutely the incommensurability of the witches' two styles of speech: that of the 'women of the very lowest class' and that of the Delphic Oracle. But precisely in that discrepancy, he thought, there lay the power of the play: Shakespeare combined the rudimentary terror of popular superstition (old women with the power of the evil eye, for example) with an intelligent, philosophical sort of terror, the 'Destiny of the ancients'.

8 David Rosen and Andrew Porter, eds., Verdi's 'Macbeth': A Sourcebook (New York, 1984), 346-8; August Wilhelm von Schlegel, Sämmtliche Werke, ed. Eduard Böcking, vol. VI (Hildesheim, 1971), 254-6. 
But Schlegel does not say which role is fundamental. Are the witches Destiny itself in drag? Or are they normal old women, like the druids in Goethe's poem 'Die erste Walpurgisnacht', who have mastered an effective charade of heebie-jeebies for frightening the populace? Objections can be made to either argument: it is hard to get the witches in focus. Shakespeare seems to have placed them in a condition of such pure play that it is impossible to ascribe a fundamental role to them: they have their prop-box of fake beards, funny-looking things to throw into a pot; they have their poem-box of startling metres for magic charms; but beneath costume and spell they are abstract isolates of theatre, with not much extra-theatrical reference. They are drama-blotches, which we choose to construe as gagging crones or as highfalutin' hypotyposes of cosmic design, as it suits us. Shakespeare's art is to make a representational sort of theatre into the frame around an actor's workshop: the credible exterior drama continually encroaches on some obvious makeshift, a dumb-show of auricular homicide, a pretend place-switching of a prince and a fat fool, a lesson for amputees in a method of writing in sand with the stumps of one's arms, a game of reading the shapes in clouds, a recipe lecture from hell's own Julia Child. Our insistence on endowing costume dummies with subtle facial expressions, on manufacturing deep meaning from loose skits in a self-dismantling play, is responsible for much of Shakespeare's power. But all deep meaning in art is like this: the provision of rifty dysfunctional areas (the breakdown in the first movement of Beethoven's Appassionata sonata, the grey blur at the centre of Manet's Music in the Tuileries Gardens, the raw rock in Michelangelo's Rondanini Pietà) that become effective metaphors for our zones of ignorance, where great things seem to dwell. The witches are indeed the 'weyward sisters' (1.3.32), at once weird and wayward, eerie and obstinate. They represent the perversity of fate itself, the waywardness of Wyrd, the Old English name for fate.

\section{Verdi's theory of demons}

Schlegel's criticism of Macbeth was to have important consequences in the history of opera, because an Italian translation was appended to Carlo Rusconi's 1838 translation of the play, Verdi's principal source. (Indeed the English translation quoted above has been revised to reflect what Verdi actually saw.) Verdi peered at Shakespeare's witches through Schlegel's optic; and Schegel is partly responsible for some of the disturbing features of Verdi's treatment.

For one thing, Verdi's witches, like Schlegel's, are compound creatures: 'women of the very lowest class' and yet solemn oracles. Their moods shift quickly, as if they dwelt in a continual mad scene, or enacted the insanity of fate itself. Near the beginning of the Macbeth project, Verdi sent his own draft of a libretto to the official librettist, Francesco Maria Piave, with the instruction to 'adopt a sublime diction, except in the witches' choruses, which must be vulgar, yet bizarre and original [triviali, ma stravaganti ed originali]'. ' One might have thought that self-conscious

9 Verdi's 'Macbeth', 8. The surviving correspondence of Verdi and Piave concerning Macbeth, along with much else of great interest, is translated in Rosen and Porter's Verdi's 'Macbeth': A 
triviality was a twentieth-century phenomenon (as in Poulenc's Banalités); but Verdi wanted his witches to sound trivial and extravagant - perhaps as close as the vocabulary of the age could come to the term 'camp'.

How trivial are Verdi's witches? Historically, listeners have answered, much too trivial. In 1930 Verdi's biographer Francis Toye wrote that the witches' music must be 'dismissed as another of Verdi's failures in the domain of the fantastic'. ${ }^{10}$ In 1973 Julian Budden claimed that the first witches' chorus 'does not add up to anything very terrifying ... it at least captures the essentially childish malice of the witches in the play'; as for the second witches' chorus ('Le sorelle vagabonde'), it 'has all the deliberate vulgarity of its predecessor without any of the fantasy. It is just any chorus of gipsies or peasants'. ${ }^{11}$ By the standards of the finest Schauerromantik of Verdi's age, such as the Wolf's-Glen scene in Weber's Der Freischütr. (1821) or Emmy's romance from Marschner's Der Vampyr (1827), Verdi's witches can seem comically underhorrified - peppy, freakishly high-spirited, but harmonically tame. On the other hand, Verdi's contemporaries greatly enjoyed the witches; on the night of the première, 14 March 1847, the numbers for which the audience demanded an encore were the first-act duet - by common consent one of the triumphs of the whole Verdi canon - and the witches' choruses. ${ }^{12}$ Verdi approached the problem of witch music from an angle wholly different from that of Weber or Marschner - but it is arguable that Verdi's imagination of the fantastic is equally successful. I don't mean at all to belittle the critics of previous generations: they were responding to the fact that there is something wrong, uneasy-making, about Verdi's depiction of witches - as indeed there is.

By 1847 Verdi was an experienced hand at writing fantasy-music, and at writing just about everything else relevant to opera. In Verdi's previous operas the closest analogue to the witches of Macbeth is the chorus of demons in Giovanna d'Arco (1845). These demons, tempting Joan of Arc to open her heart to a tenor's love instead of pursuing her high mission to save France from the troops of England, are easy to ridicule, and the older critics did ridicule them: Toye comments, 'they indulge in a 3/8 lilt, intended, as is so often the case with this rhythm, to be seductive, but actually suggesting comic-opera peasants and fishermen'. ${ }^{13}$ Budden finds this $3 / 8$ section ('Tu sei bella') 'bland and tuneful. ... It has an innocent vulgarity which reeks of the Neapolitan café'; concerning the demons' most remarkable music - the 'Vittoria' chorus at the end of the first act, a paean to their success at forcing Joan to fall in love, to compromise herself - Budden remarks 'the entire episode is a tasteless and feeble excrescence'. ${ }^{14}$

But it is possible that Verdi liked an altogether different sort of demon from those that conform to old-time standards of diabolic propriety. It is the business of a

Sourcebook.

${ }_{10}^{10}$ Francis Toye, Giuseppe Verdi (New York, 1959), 265.

11 Julian Budden, The Operas of Verdi, vol. I (New York, 1973), 282-3.

12 Verdi's 'Macbeth', 54.

13 Toye, Giuseppe Verdi, 250-1.

14 Verdi's 'Macbetb', 212, 217. 
tempter to tempt; a seducer who accompanies his subtle coaxings and blandishments with loud string tremoli, diminished sevenths, trombone rumblings and piccolo shrieks is not likely to succeed. There is an operatic convention that demons should wear a musical badge proclaiming DEMON at every instant of their time on stage. But Verdi was under no obligation to follow this convention by compelling the orchestra to ironise the seduction with heavy demon tropes. Perhaps Joan of Arc, or her Italian alter-ego Giovanna d'Arco, might plausibly find the tinta of a Neapolitan café more conducive to sexual surrender than that of the Flying Dutchman's zombie crew. When at last the demons reveal themselves as demons, they are transformed into figures of wholehearted evil: they sing a fanfare that is simply a build-up of a diminished-seventh chord. (Verdi was self-conscious about the stock effect of such chords: in 1871, he called them 'that rock and refuge of all those of us who can't compose four bars without half a dozen of those sevenths'. ${ }^{15}$ ) There is no ambiguity, no tension in the demons' ways of presenting themselves: first they were guitar-strumming café flatterers - a role they played so well that they even fooled the orchestra - and now they are obvious demons. The ambiguity and the tension belong entirely to Joan, who, during the first-act finale, is audibly nervous: the music reproduces her gooseflesh, her irregular heartbeat, her panting. This is the Italian model of the supernatural: simple musical stimuli and a complex musical response - as opposed to the Franco-German model of building the listener's response (bristling hair, popping eyes, intake of breath to scream) into the stimulus itself. Berlioz's or Gounod's Méphistophélès is richer than his Faust; but Verdi's Joan is richer than Verdi's demons.

Verdi, then, is a literalist of the supernatural, in that he presents the fantastic creature to the audience in way that simulates the creature's appearance to the other characters on stage - Verdi always understands that terror pertains not to the creature (why would it be terrified of itself?) but to those onstage who behold it.

Macbeth shows two souls who are challenged with more fantasy than they can bear. Joan of Arc had to cope with one, and only one, sort of fantastic deception; but the Macbeths have to deal with Houdini's whole battery of tricks. I say tricks, but the witches are remarkable for their utter frankness about their prestidigitergiversations. In Marlowe's Doctor Faustus, as in many subsequent Faust-plays, Mephostophilis is imperturbably open about the worthlessness of the gifts he offers: he replies, when Faustus asks him how it is that he can leave hell, 'Why this is hell, nor am I out of it. ... O Faustus, leave these frivolous demands, / Which strike a terror to my fainting soul' $(1.3 .76,81-2)$. Verdi's witches do everything they can to expose their triviality, their sheer facetiousness of being. They are far more like Robert Johnson's Hecate than like Marschner's vampire.

The mid-twentieth-century critics are offended precisely because they don't want witches to sound trivial. Budden can't stop excoriating Verdi's witch music: in the chorus at the end of the first scene 'the minor section is superior to the major which sounds all too like a Neapolitan street song' - Budden hears a lot of bad Naples in

15 Budden, The Operas of Verdi, vol. 3 (New York, 1973), 505. 
Verdi. ${ }^{16}$ Where the modern ear wants something deviant and exciting, Verdi provides disgustingly normal-sounding music. But the disgust of the ordinary was exactly the sort of disgust Verdi meant. His witches gain a certain strength from having their coarseness so blatant. Here Verdi's practice anticipates Freud on the uncanny, das Unheimliche, a condition in which slight displacements of the familiar achieve a state of terror: the very commonplaceness of the witches makes them insidious. If Verdi's demons and witches rarely stray from the cafés of Naples, it is because the scariest things happen there. Verdi's witches seem most at home when singing nondescript music in major keys; when they sing in the minor, it is often part of a show put on in order to befool Macbeth, a piece of conscious hokiness - they veil themselves in the musical equivalent of robes painted with mysterious emblems.

In this respect Verdi's music is exactly congruent with the witch-costumes designed for the first production. The Gazzetta musicale di Milano (22 December 1847) described a lithograph of a witch from Macbeth (one of the bonus figurini sent by Giovanni Ricordi to opera subscribers) as follows: 'A Bedouin mantle with a fire-red hood; a robe embroidered, at its lower extremity, with little monsters; a broad belt and buckle, and, hanging from it, the type of Imperial purse to which fashion writers of the time gave the name of ridicule [i.e., 'réticule']; the footgear of the Hottentots [i.e., none at all], a cane or magic wand in the right hand, and on her chin the pointed beard of the Arabs'. ${ }^{17}$ The newspaper writer saw in the witch's costume a bizarre geographical mélange, with elements from Arabia, Africa, and contemporary women's fashion; but this account neglects to mention that these near-random assemblages from the prop box are fastened to the plainest sort of dress: a belted shift, with raggy edges. It is as if a beggar-woman had stumbled into Ali Baba's cave, and plucked out a few loose treasures. The costume is mysterious in its poverty as well as in its flair for incoherent details. In Paris, at the Bibliothèque de l'Opéra, there is a drawing for a Macbeth witch-costume, quite clearly based on the 1847 lithograph described above, but with one fascinating difference: the long sash, dangling down to the witch's knee like a big phallus, is decorated not with snaky monsters but with vaguely Arabic letters, runes, as if the witch wore her incantations visibly imprinted on her clothing (Fig. 1). ${ }^{18}$ But she too wears a shift that ends in zigzags, as if the cloth had been torn, not cut. The witch's spell, her virtus, her manhood, seem decorative in character; beneath all the fanciness she's a vulgar old woman. King James emphasised that witches were nothing but old women who had gone astray-and Verdi's witches seem to follow good Jacobean principles of sorcery.

\section{Oracles}

One of the defining moments in Verdi's witch-music occurs early in the opera, when the witches hail Macbeth as Thane of Glamis, Thane of Cawdor, King of

16 Budden, I, 284.

17 Verdi's 'Macbeth', 419-20.

18 Verdi's 'Macbeth', 193. 


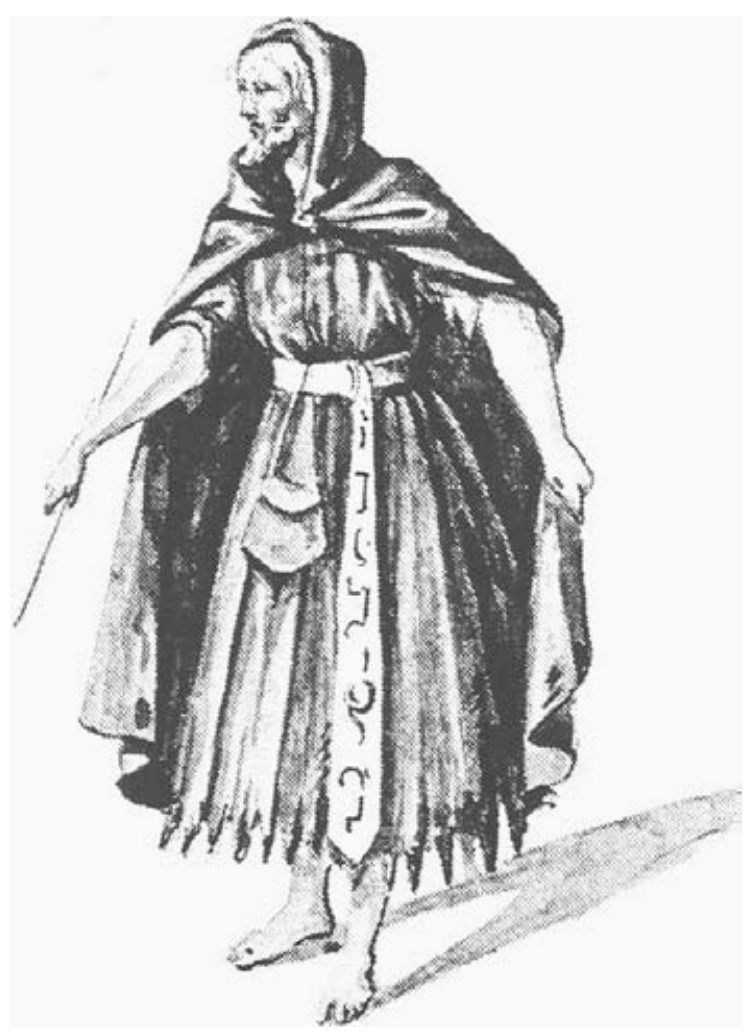

Fig. 1: Witch's costume

Scotland. By 1847 Verdi had developed a specific style for epigram: a way of thickening a terse melody into a sort of stage-object, something to be wielded, just as a character might wield a sword. Conspicuous examples can be found in Emani (1844), in the rhyme that commands Ernani's suicide, or in Attila (1846), when Attila dreams of a huge old man who bars his path to Rome, saying:

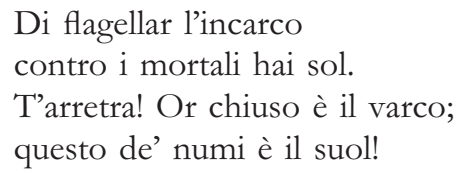

[You have been given the one task, to scourge the wicked race of men. Turn back! You now face a closed path; this is the land of god alone!]

Soon Pope Leo will confront the army of the Huns, and speak those very words. The music acquires a cybernetic force, and Attila, for all his barbaric might, trembles before a minor scale with an augmented fourth. During the 1840s Wagner was making similar experiments with musical epigrams, such as the Pope's curse on Tannhäuser. Neither Wagner nor Verdi used these epigrams as leitmotifs: they are stiff, self-contained phrases, with none of the plasticity, the combinatorial ease typical of the leitmotif; in most cases they are expanded cadences with a sharp melodic profile, not a continuation of the previous musical discourse but an 


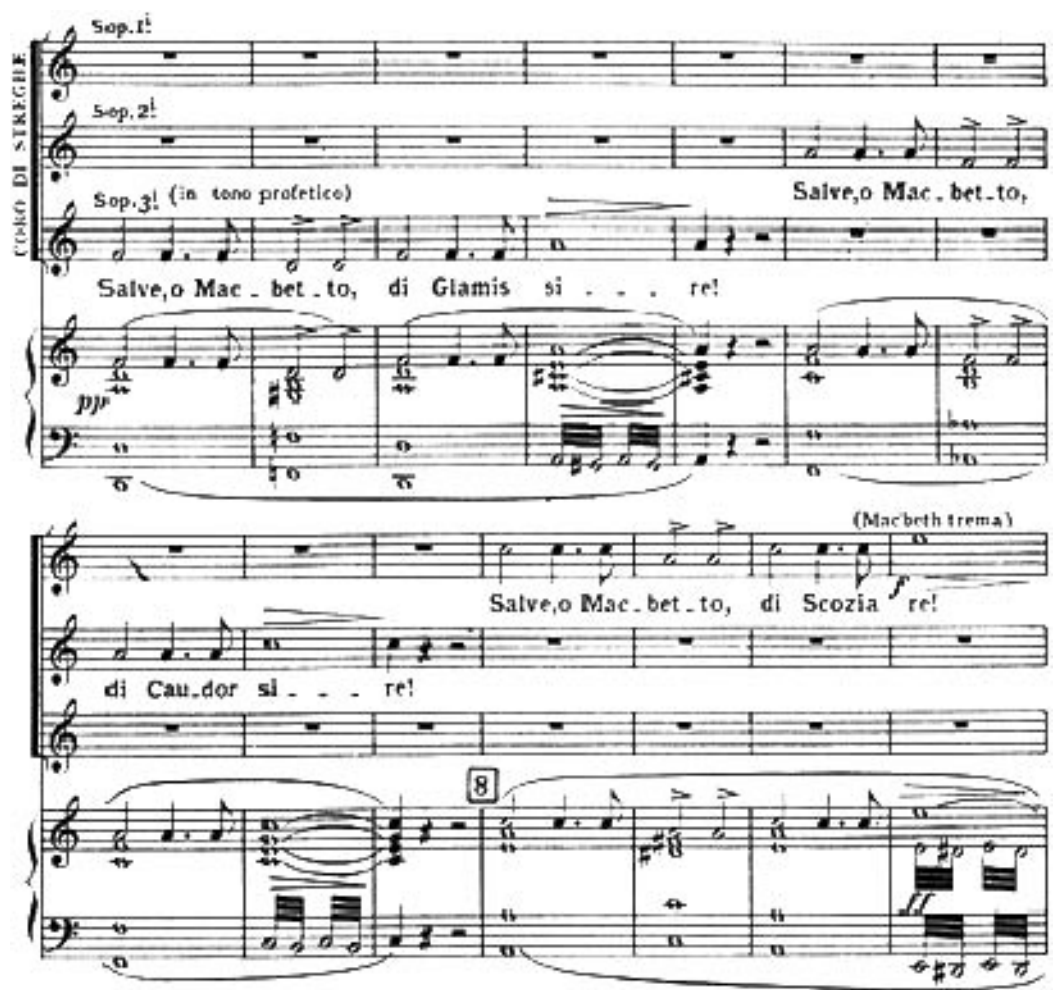

Ex. 2: Verdi, Macbeth, 'Hail!'

interruption of it. An epigram is not an episode in a symphonic development but a unit of music theatre, in which music objectifies itself into something abrupt, hieroglyphic, legible. Often it follows the exact contours of words: but it is the meaning of the words, not the phonetic structure, that the epigram seeks to memorise, to freeze.

In Macbeth this sort of music-speech is appropriate for all sorts of oracles and sentences of terror - just as the witches' sashes are figured with runes, so their prophecies are conveyed through epigrams:

\section{Salve, o Macbetto, di Glamis sire! \\ Salve, o Macbetto, di Caudor sire! \\ Salve, o Macbetto, di Scozia re!}

[Hail, O Macbeth, Thane of Glamis! Hail, O Macbeth, Thane of Cawdor! Hail, O Macbeth, King of Scotland!]

The first line proceeds from $\mathrm{D}$ minor to a diminished chord to A major; the second from $\mathrm{F}$ major to a diminished chord to $\mathrm{C}$ major; the third from $\mathrm{A}$ minor to a diminished chord to - all logic says that the word 're' (king) must be accompanied by an E major triad, but instead we hear the single note $\mathrm{E}$, with an unhappy tremolo in the bass between $\mathrm{D} \#$ and $\mathrm{E}$, a reaction-shot of Macbeth trembling at the news ('Macbeth trema' reads the stage direction) (Ex. 2). The rudiment of this epigram 


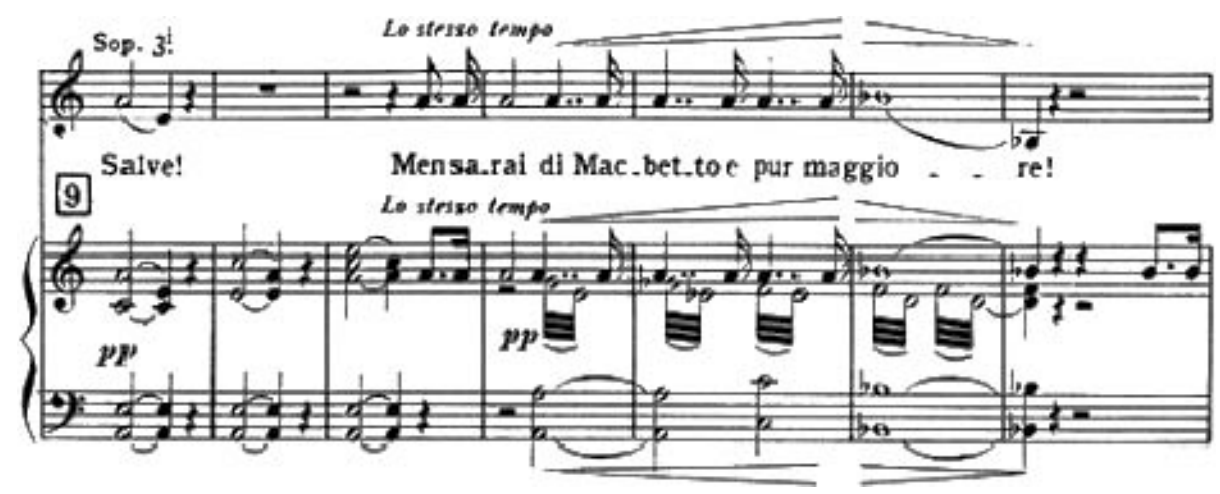

Ex. 3: Prophecy to Banquo

is a $\mathrm{i}-\mathrm{V}$ half-cadence, a very simple thing; in the construction manual of opera, this isn't much more than a standard-issue brick; but Verdi shows great resourcefulness in promoting this little cadential chunk into the rawest element of horror, the Mark of Cain itself.

Soon the witches turn from Macbeth to Banquo, and utter another epigram (Ex. 3):

Men sarai di Macbetto e pur maggiore!

Non quanto lui, ma più di lui felice!

Non re, ma di monarchi genitore!

[You will be less than Macbeth, yet greater! Not so much as he, but happier than he! Not king, but father of monarchs!]

Here each phrase is chanted to a single note, rising a half-step on the last syllable, which become chant-tone of next line - first $\mathrm{A}$, then $\mathrm{B} b$, then $\mathrm{B}$, rising to $\mathrm{C}$ at end of 'genitore', with the final syllables of each phrase underlined by major triads. This sort of upward crawl had long been a useful formula for oracular speech: Purcell used it for conjuring pagan gods in The Indian Queen (1695). But at this point comes something unexpected and characteristically Verdian: the witches instantly abandon their mood of vatic trance and break out in a frivolous jingle, 'Macbetto e Banco vivano!' (long live Macbeth and Banquo!), supported by basic C and G chords (Ex.4).

It is as if the Cumean Sibyl, wreathed in incense, sitting on a throne hewn out of cave rock, muttering incomprehensible sentences with her eyes shut in ecstasy, suddenly rose, danced a little grinning jig, clicked her heels, and held out her arms to invite applause. Verdi has a similar effect in Falstaff, when Alice continues Quickly's creepy-crawly story of the hunter at Herne's Oak, full of strange string tremoli and brass blasts, but then laughs it off as a mere fairy tale to entertain children before bedtime.

Why do the witches behave in such an undignified, even unwitch-like manner? One explanation is that they are deriding any human attempt to solve their riddles, to evade their power. But in the light of Verdi's comment on the mixture of the solemn and the trivial in Shakespeare's witches, another possibility presents itself: the witches are deliberately undermining themselves, exposing the fatuity at the 


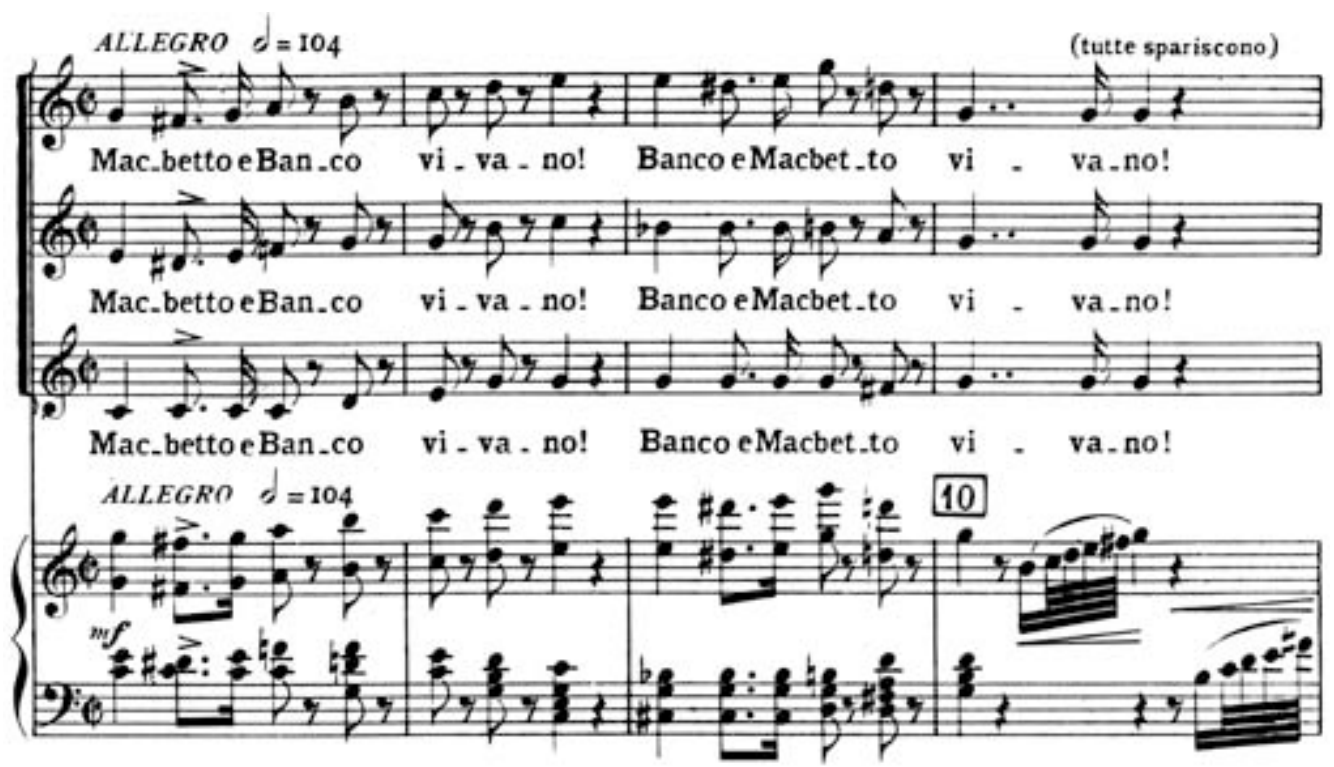

Ex. 4: Long live Macbeth and Banquo!

heart of their spectacles of terror. The sash with its mystifying alphabet is fastened loosely, and tends to fall off, exposing the witches as silly raggedy old women with a gift for freak shows. They dismiss Macbeth, and the human race, and finally themselves. Beginning as instruments of tragedy, agents of a divinity that shapes our ends, rough-hew them how we will, the witches end as vehicles of a universal inconsequentiality. Here Verdi and perhaps Shakespeare too go beyond tragedy. Tragedy depends on some sense that Fate has dignity, even if human beings have none; but the witches of Macbeth impinge on a vision of the random. What if Fate itself is a threadbare woman putting on cheap theatrical tricks to tease us with the hope that disorder might be understood as malevolent order?

\section{Sortileges of speech}

The bite of a vampire can turn the victim into another vampire; and similarly Verdi's witches exert a field of force that turns others into witches - especially (as we shall see) Lady Macbeth, who has no direct contact with them. Even the witches' oracular rhetoric is strangely contagious: the great Act I scene and duet for Macbeth and his wife occurs not long after the scene with Macbeth and the witches, and it is remarkable how much both the protagonists start to sound like witches. They start to talk to one another in epigrams.

Just as the witches could hardly keep a straight face as they delivered their prophecies, so the Macbeths' epigrams retain their serious demeanour with a certain difficulty - they tend to decay into gestures of meaningless fuss. The Macbeths tend to get stuck on a single musical phrase, unable to proceed. For a first look at the operations of a repeated epigram, let us examine the Scena e Marcia (1.2). Macbeth 

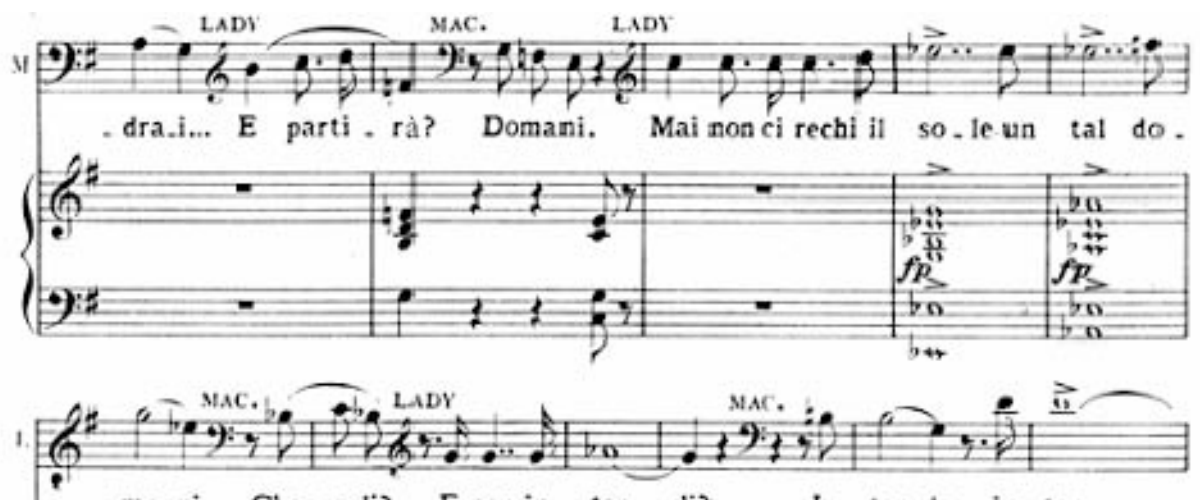

ma.ni. Che parli? E non in - ten - di? In - ten.do, in - ten..

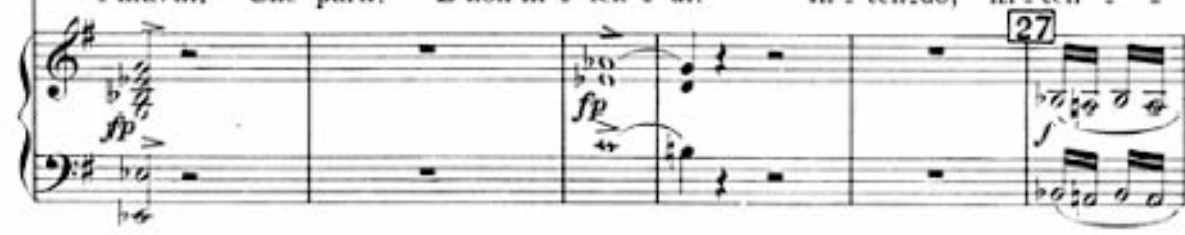

Ex. 5: No tomorrow

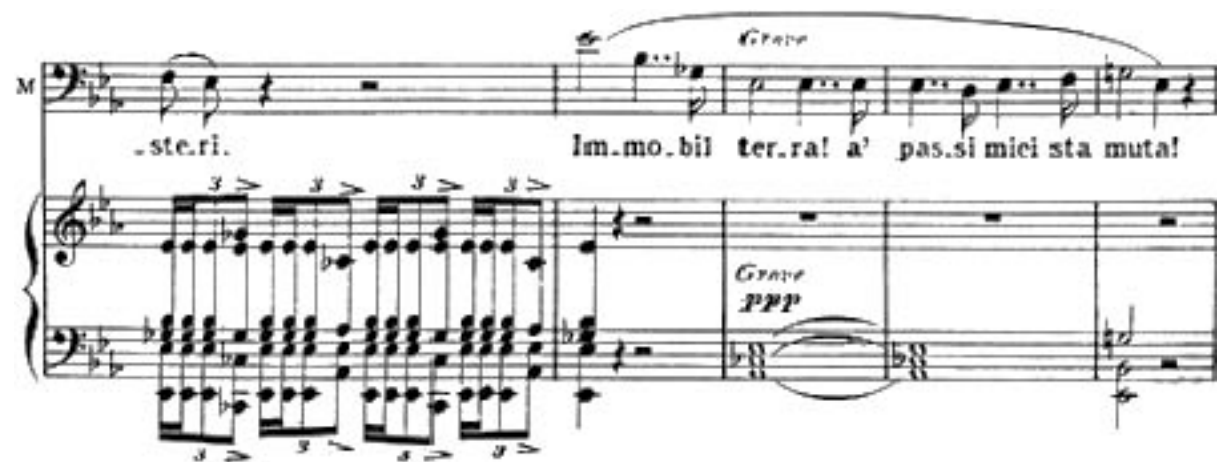

Ex. 6: Unmoving earth

enters - Lady asks him when the king will be leaving, and he replies 'Domani' ('tomorrow'); this news inspires her to devise a memorable omen: 'Mai non ci rechi il sole un tal domani' ('may the sun never bring us such a tomorrow'), her vocal line inching up the first fifth of the $C$ minor scale, then falling back from $G$ to $E b$, with a plagal cadence in the orchestra (Eb-Ab-Eb major) (Ex. 5).

The melody of this black prayer will often reappear, in various forms: beginning later in this act when Macbeth addresses a request to the 'immobil terra, a' passi miei sta muta!' ('unmoving earth, be mute to my footsteps!' - a harmonic movement from Abminor to Eb) (Ex. 6).

And at the very beginning of the second act, Macbeth and his wife (whom Verdi and Piave call simply Lady) mull over the consequences of the assassination in a short passage that is simply a tissue of this epigram, repeated over and over. First Lady tells Macbeth, 'Why worry? Il fatto è irreparabile!' ('The deed is irreparable!' - Gb minor to Db major) (Ex. 7). 


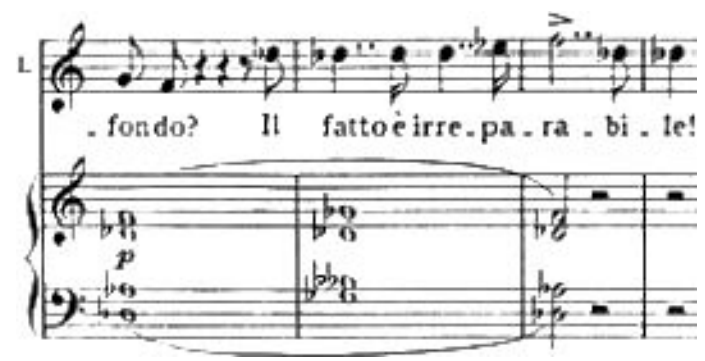

Ex. 7: Irreparable deed

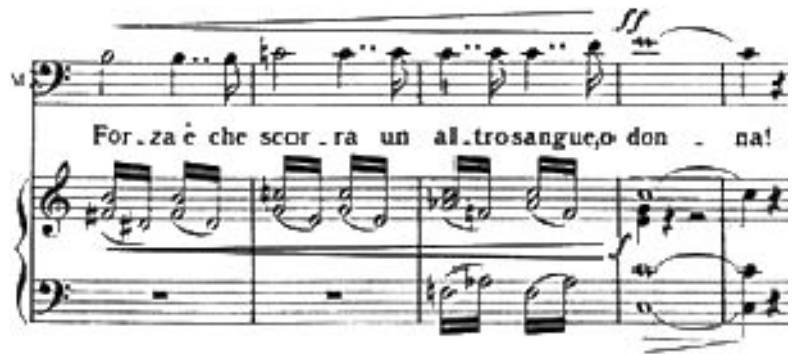

Ex. 8: Other blood must flow

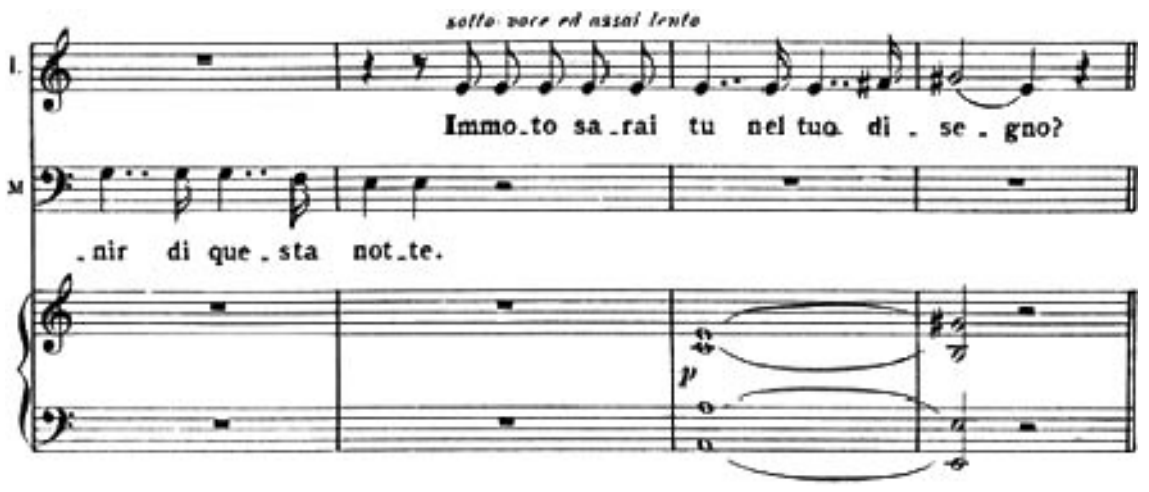

Ex. 9: Will you be unmoved?

But Macbeth remains worried, and announces, to the same tune, 'Forza è che scorra un altro sangue, o donna!' ('It is fated that other blood [Banquo's and his children's] must flow, O lady!' - F minor to C major) (Ex. 8).

Lady agrees that these secondary murders must happen quickly, and asks Macbeth, again to the same tune, 'Immoto sarai tu nel tuo disegno?' ('Will you be firm in your intention?' - A minor to E major) (Ex. 9).

The Macbeths have become stuck on this little obsessive figure, a circumflex mark that rises through a fifth or a third, and finally drops a third, over (in its later appearances) a sin-coloured $\mathrm{i}-\mathrm{V}$ half-cadence, the insignia of terror. Immobile words such as 'immobil', 'immoto', 'irreparabile' tend to activate this figure; it is a musical exclamation point, a needle that gouges these sentences into the surface of 
the mind. Here we have the epigram of evil resolution, a musical image of the irreversibility, the un-undoability of acts. The music proclaims what's done is done.

In a remarkable essay Marjorie Garber has found many traces of the Medusa legend in Macbeth - a severed head, a battery of mirrors, hair standing on end. ${ }^{19} \mathrm{I}$ see evidence in the foregoing scene of petrification: the music has simply stopped, and Macbeth and his wife keep repeating the same little phrase together - they're caught in a folie à deux , at least for a moment, prefiguring the monomania of Lady in the sleepwalking scene in the last act, when she is caged up in her handful of tiny musical phrases. In Act I Macbeth and his wife are gorgons to one another - both seem to turn to stone. The whole scene anticipates the strange little game Iago and Otello play in the second act of Otello, a version of the game from Duck Soup in which Harpo and Groucho Marx face each other in an imaginary mirror. Otello notes that Cassio conveyed presents from Desdemona, and Iago replies, 'Dassenno?' ('Indeed?') and Otello says, 'Sì, dassenno. Nel credi onesto?' ('Do you think her honest?'). Iago repeats 'Onesto?', to which Otello says 'Che ascondi nel tuo core?' ('What are you hiding in your heart?') Iago repeats, as if the sentence didn't have any meaning, 'Che ascondo in cor, signore?' ('What am I hiding in my heart, lord?') and Otello again reflects the same words back at him, to the same tune, like a parrot, 'Che ascondo in cor, signore?' From 'onesto' on, these phrases all begin with the same three notes - it is not easy to tell who is the singing coach and who the slow-witted pupil, but the audience knows that Iago, usurping Otello's voice, is calling the tune. Temptation scenes play in Verdi's head as a form of echolalia.

Macbeth and Lady at last escape from this prison of echoes, and the musical discourse changes rapidly, from a near-perfect stasis to a near-perfect disorder. Macbeth sees the apparition of the dagger ('Mi si affaccia un pugnal?!') as the orchestra contributes a whole consort of aural hallucinations: ferocious but unsteady and fugitive rhythms; a chromatic cello line, insinuating, rising to light like a bad intention ('A me precorri sul confuso cammin') - at last the twisty melodies gutter out into a shadowy intricacy of diminished chords ('Sulla metà del mondo or morta è la natura'). This passage is near Verdi's limit of derangement in musical thought: the witches' love of random spastic phrases, their habit of turning the riddle, seems to have infiltrated all speech, leaving only a heap of stray ominousnesses. In these hectic gestures Macbeth, like a witch, reads the future: he will be king.

Macbeth leaves, intending to kill Duncan; when he re-enters, 'as if choking', he announces 'Tutto è finito!' ('All done!') to a simple minor-second figure, at the threshold of recognition as a epigram (Ex. 10).

As many critics (starting with Abramo Basevi in 1859) have noticed, Verdi will construct a number of important figures along identical lines. ${ }^{20}$ We can hear 'Tutto è finito' in Macbeth's description of the voice that says Macbeth doth murder sleep ('Allor questa voce'); in the opening of the great choral lament in the finale to the

19 'Shakespeare's "New Gorgon", in The Medusa Reader, ed. Marjorie Garber and Nancy J. Vickers (New York, 2003), 249-57.

20 Basevi, Studio sulle opere di Giuseppe Verdi, cited in Gary Tomlinson, Metaphysical Song: An Essay on Opera (Princeton, 1999), 96. 


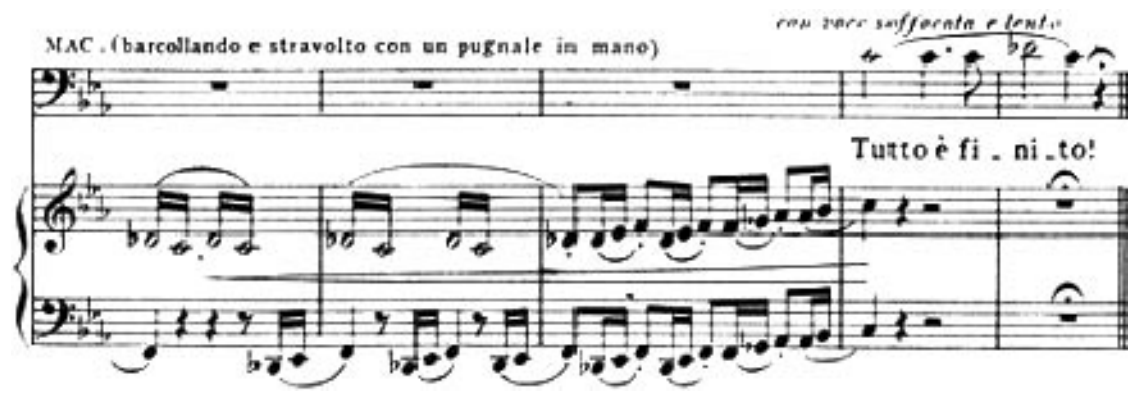

Ex. 10: All done

first act ('Schiudi, inferno'): and the first three bars of the prelude to the second act, obviously recalling 'Tutto è finito', note for note; and even the words 'Una macchia' ('a stain') in the sleepwalking scene, a subtle recollection. ${ }^{21}$ This little figure is the music-icon of the stain that can't be washed out - and since in a tragedy falling minor seconds, the basic figure of desolation since the days of Monteverdi's stile molle, are likely to be everywhere, Verdi teaches us to read them as an omnipresence of blood. Verdi spatters his score with incriminating spots.

\section{Lady Macbeth as a witch}

In some ways the Gran Scena e Duetto of Act I is far more of a black sabbath than anything found in the witches' own music. At the beginning of the scene Verdi notes in the score that the singers must sing in a hushed and dark voice, unless instructed otherwise. Verdi wanted something that was, as far as I know, unprecedented in the domain of nineteenth-century Italian opera, a set-piece that was melodically intense - not recitative - and yet took place in some boundary region between speech and song. A letter of Verdi's (7 January 1847) to the baritone who created the role of Macbeth, Felice Varesi, makes this point clear: 'I'd rather you served the poet better than you serve the composer. ... In the grand duet ... Note that it's night; everyone is asleep, and this whole duet will have to be sung sotto voce, but in a hollow voice such as to arouse terror'. ${ }^{22}$ Verdi was often to repeat this advice. The word 'hollow' ('cupo') governed Verdi's whole imagination of Macbeth; it is a subterranean sort of opera, as if the performance were constituted within a cave, or as if the singers each sang from within a private abyss. Indeed words such as 'cupo' and 'gufo' ('owl') seem to brood over the text - perhaps the epigrams about immobility and irreparability, with their $\mathrm{i}-\mathrm{V}$ half-cadences, their soft falls of a third, in some sense reproduce the sound-tint of these very words. In this opera, even more than Otello, Verdi comes closest to realising the old dream of the inventors of opera, a tragedy in which speech rises effortlessly, imperceptibly, into

${ }^{21}$ Gary Tomlinson offers an exceptionally full catalogue of these 'Tutto è finito's, often in the form of falls from scale degree b6 to 5, in his Metaphysical Song, 96-9. See also Pierluigi Petrobelli, Music in the Theater: Essays on Verdi and Other Composers, trans. Roger Parker (Princeton, 1994), 144-5.

22 Verdi's 'Macbeth', 30-1. 


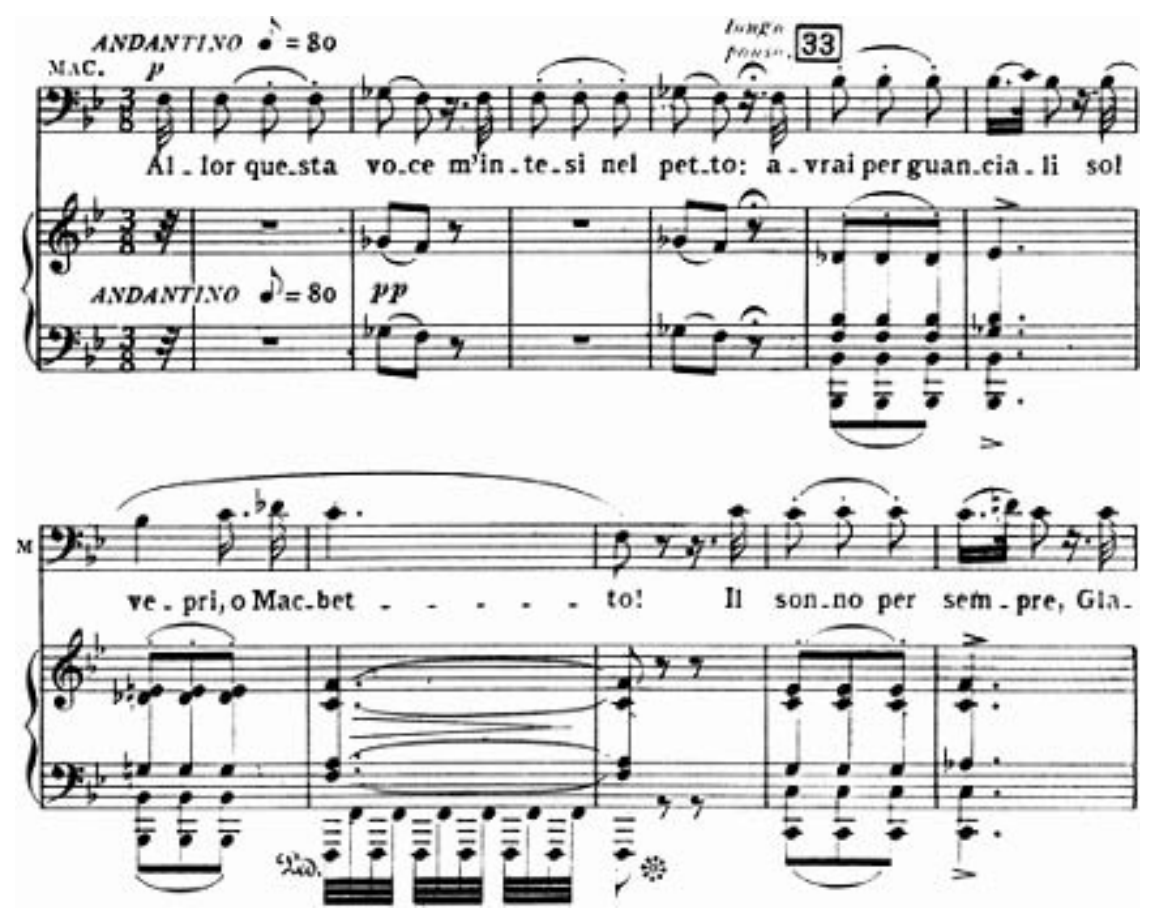

Ex. 11: Only thorns for a pillow

song. When Verdi in 1875 compared his achievement to Wagner's, he noted, 'I, too, have attempted the fusion of music and drama ... and that in Macbeth'. ${ }^{23}$ Verdi hadn't yet written Otello or Falstaff, but in those late operas he approached Shakespeare through the highly wrought, semi-opaque medium of Boito's poetry and dramaturgy, whereas Piave provided a fairly clear image of the original Jacobean text.

Verdi's great achievement in this liminal area far beneath bel canto, where singers make whispery harsh sounds, is the duet 'Fatal mia donna!' - an astonishing psychological study of the tremors of spiritual remorse combined with the hilarity of gratified ambition. The large-scale dramatic rhythm of the duet is terror followed by mockery of terror. We saw this rhythm - first, solemn prophecy, then, happy sneer - during the witches' prophecy to Banquo in Act I; and Lady, by aping their behaviour, is turning before our eyes into another witch. When Macbeth, fresh from killing Duncan, tells his wife that he felt like saying 'Amen' as the footmen were praying 'May God help us', she interjects 'Follie!', decorating her line with bright little grace notes, as if she were playing the role of his private Vice, an internal voice laughing at his scruples. Macbeth tells her of the voice that accuses him of murdering sleep, 'avrai per guanciali sol vepri, o Macbetto' ('you will have only thorns for a pillow, O Macbeth’) (Ex. 11).

23 Verdi's 'Macbeth', 125. 


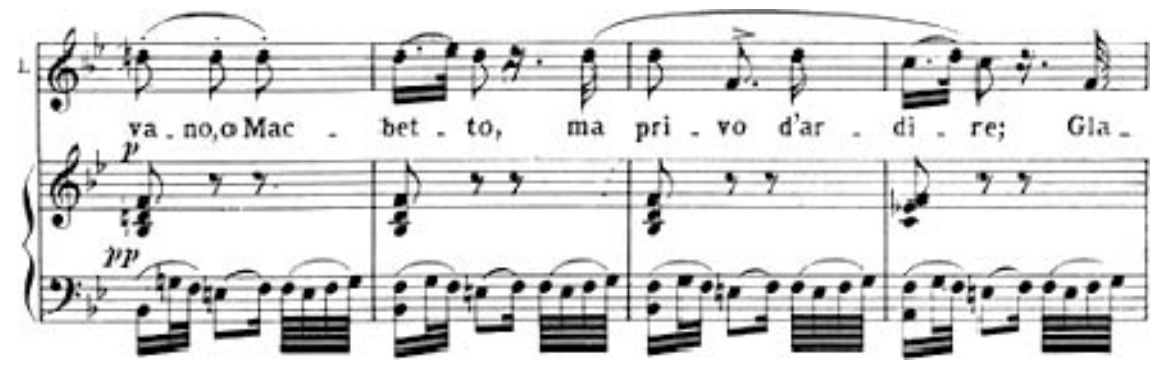

Ex. 12: parody

Lady immediately quotes this tune back to him, suggesting that the phantom voice was really saying 'Sei vano, o Macbetto, ma privo d'ardire' ('you are vain, O Macbeth, but not bold enough') (Ex. 12).

Lady recasts Macbeth's B flat minor phrase in a jingly, cheerful B flat major - a parody that again suggests the effect of psychic intimacy she is trying to achieve, as if she were a second point of view inside Macbeth's skull, offering alternative interpretations for the same event.

Lady infects Macbeth's imagination by echoing him - we are back to the prison-of-echoes game from earlier in the scene. She attempts to regularise his musical discourse, to fetch him out of a traumatic realm of minor keys, diminished chords, black cadences, sudden silences and hesitations, fragmentary phrases, oracular ambiguities, into a straightforward, major-key domain of resolute action. But by quoting Macbeth she seems less to shake him out of his madness than to join him in it - as if she were a psychiatrist beset by counter-transference, following her patient a little too far into psychosis. By encouraging Macbeth to bring the witches' prophecy to pass, she becomes in effect another witch - her very lack of a first name seems to abstract her from society, from the realm of nameable deeds. Near the climax of the duet, Lady, exasperated, decides to incriminate the footmen herself; she manages to exit the stage, smear blood, and return to the stage in a space of sixteen bars of quick music - she works in witch's time, foreshortened and accelerated, not human time. Harold Powers has studied with great care and sensitivity the ratios of stage action to musical action in Verdi's operas; he points out that excited music, as in cabalettas, often implies stasis on stage, and that the actors were permitted to move only at specific points in an aria, duet or finale. ${ }^{24} \mathrm{I}$ think of Lady's super-fast exit and re-entrance as almost a parody of the tempo di mezzo, the kinetic interlude just before cabaletta or stretta. Time is becoming unnatural; the clock is out of whack.

Despite her recommendations of directness, forward thrust, Lady seems strangely shapeless and helpless, as if she had no identity except what she could borrow from others. She is happiest when singing other people's music, or pre-existing public display pieces such as the brindisi; left to her own devices she tends to adopt the musical mannerisms of the witches - she has never heard the witches, but it seems

${ }^{24}$ Harold S. Powers, 'Making Macbeth musicabile', in 'Macbeth': Giuseppe Verdi, English National Opera Guide 41 (London, 1990), 21. 
that she can hear everything Macbeth hears, even hallucinatory voices. Near the beginning of the first act, the witches utter dark spells, then laugh at themselves; near the end of the first act, Macbeth utters dark spells, then Lady laughs at him. The Macbeths effortlessly fall into a sort of actors' class exercise in playing witches - an exercise itself devised by witches.

For Verdi, the supernatural tends to be a region of mockery. Witches open up a free space where desire may operate in an unusually unconstrained manner. But there is no true safety in the supernatural, for giving in to bad desire leads to extraordinary humiliation - and, with the possible exception of Shakespeare, the master of the candied smile, Verdi was more expert in derision than any artist I know. Detached 'ha-has' that threaten to break out into an evil little dance, suppressed titters faintly registered by the orchestra, vocal trills gone giddy with malice - what composer can compete with Verdi in such effects? Most of Verdi's witches are surrogates for Fate, deriding mankind; and when Lady derides her husband, she assumes the witch role without quite understanding that the only spectacle that delights a witch is the spectacle of ruin.

Verdi provided a clue that he imagined Lady as a kind of witch, or witch manquée, or apprentice Vice, a woman attempting to reconceive herself along diabolical lines. In a letter (8 February 1865) to Léon Escudier, concerning the newly revised French version of Macbeth, Verdi wrote 'The witches dominate the drama: everything derives from them - coarse and gossipy in the first act, sublime and prophetic in the third. They are truly a character, and a character of the utmost importance.... The important character, the dominating demon of this [banquet] scene is Lady Macbetb; and however much Macbeth can distinguish himself as an actor, Lady Macbeth dominates and controls everything. ${ }^{25}$ The witches dominate the drama, but Lady dominates everything; Verdi never developed an articulate theory about Lady's relation to the witches, but he evidently understood Lady as a character struggling to achieve the witches' manipulative force, uncanny authority. Like the witches, she devises impresses spectacles; and like the witches', her spectacles turn out to be hollow.

\section{La sonnambula}

By the Italian standards of the 1840s, Macbeth is nearly an anti-opera, since no one falls in love, the lead singers were carefully chosen for their unattractive voices, and the few pieces that invite vocal display often have an undertone of something hideous or stupid, as if vocal display were forced to confess its own meretriciousness.

The centre of Macbeth is the Gran scena del sonnambulismo, a scena without an aria - perhaps it could be called an anti-aria, indeed an anti-mad-scene, in the way that Mary Ann Smart has spoken of Azucena's music as an anti-mad-scene. ${ }^{26}$ As Verdi advised the first Lady, Marianna Barbieri-Nini, on 31 January 1847:

25 Verdi's 'Macbeth', 99.

${ }^{26}$ See Mary Ann Smart, 'Representations of Madness in Early Nineteenth-Century Italian Opera', Ph.D. diss. (Cornell University, 1994). 
the sleepwalking scene ... so far as the dramatic situation is concerned, is one of the most sublime [piu alte] theatrical creations. Bear in mind that every word has a meaning, and that it is absolutely essential to express it both with the voice and with the acting. Everything is to be said sotto voce and in such a way as to arouse terror and pity. Study it well and you will see that you can make an effect with it, even if it lacks one of those flowing, conventional melodies [canti filati, e soliti], which can be found everywhere and which are all alike. ${ }^{27}$

The Aristotelian words 'terror' and 'pity' show how far Verdi had gone in trying to force an Italian opera back into some pre-operatic, archaic model of tragedy. In the first three acts, terror predominates; but in the fourth act, terror is giving way to pity. The Scottish refugees are figures deserving pity; 'pity' is the first word of Macbeth's wheedling fourth-act aria 'Pietà, rispetto, amore'; and the sleepwalking scene is a psychiatric case-history of a mind so blasted by terror, so burnt out, so evacuated, that the spectator's pity must be evoked to fill the empty space. Lacking 'flowing, conventional melodies', Lady must rely for expression on prettily arpeggiated accompaniment figures, filling the empty spaces between the ghosts of tunes.

Verdi spent a great deal of time coaching Barbieri-Nini, the first Lady, in operatic somnambulism. In her memoir she claimed that she worked steadily for three months on the part - this was an exaggeration, but time distortions and sleep deficits figure everywhere in the role of Lady, even in the life of the singer who enacted it: 'for three months, morning and evening, I tried to imitate those who talk in their sleep, uttering words (as Verdi would say to me) while hardly moving their lips, leaving the rest of the face immobile, including the eyes. It was enough to drive one crazy'. ${ }^{28}$ On 11 March 1865 Verdi provided a similar recipe for the revised version, partly informed by his experience of watching the Italian actress Adelaide Ristori in Shakespeare's play:

$[\mathrm{W}]$ e reach the sleepwalking scene, which is always the high point of the opera. Anyone who has seen Ristori knows that it should be done with only the most sparing gestures, even being limited to just about a single gesture, that of wiping out a bloodstain that she thinks she has on her hand. The movements should be slow, and one should not see her taking steps; her feet should drag over the ground as if she were a statue, or ghost, walking. The eyes fixed, the appearance corpse-like; she is in agony, and dies soon after. Ristori employed a rattle in her throat - the death-rattle. In music, that must not and cannot be done; just as one shouldn't cough in the last act of La traviata... . Here there is an English-horn lament that takes the place of the death-rattle perfectly well, and more poetically. The piece should be sung with the utmost simplicity and in voce cupa [a hollow voice] (she is a dying woman) but without ever letting the voice become ventriloquial. ${ }^{29}$

To Verdi, 'ventriloquial' seems to mean 'toneless' (elsewhere he speaks of a voice 'with tone in it, not "ventriloquial" '); the Garzanti dictionary defines 'ventriloquo' as a manner of speaking 'a labbra semichiuse' ('with lips half-closed'). ${ }^{30}$ But

27 Verdi's 'Macbeth', 40.

28 Verdi's 'Macbeth', 51.

29 Verdi's 'Macbeth', 110

30 Verdi's 'Macbeth', 84. 
according to another definition, in which ventriloquism refers to throwing one's voice onto an inanimate object, Lady is quite ventriloquial: much of the burden of expression has been reassigned to the orchestra - the English horn performs a surrogate death-rattle. Parts of her voice have been thrown into the distance: indeed Lady has attained a state of far removal from herself, a sort of ecstasy of despair. She has contracted. Her single gesture, her brief flares of passion, are intermissions in a state of gesturelessness, paralysis, aphasia. If a corpse could sing, it would sound like this.

Jonas Barish has argued that Verdi's sleepwalking scene is not a mad scene: it is an organised, coherent piece, without the discontinuities that usually represent madness, and without the musical reminiscences to be found, for example, in the famous mad scene in Donizetti's Lucia di Lammermoor - 'here the music does not remember very much'. ${ }^{31}$ Barish has noticed a crucial feature of the scene: it turns the normal conventions for raving sopranos upside-down, almost as if Verdi had set out to write the exact opposite of a mad scene. But perhaps Verdi did this, not to stress Lady's sanity, but to portray a different species of madness. The extroverted Lucia became a better singer as she went mad, more urgently expressive, more dizzyingly melodic. The introverted Lady, on the other hand, is moving not towards a fantastic rapture but towards catatonia: fining herself down to an almost musicless state, she is losing expressivity, losing any power to sing. Donizetti's mad scene was full of pretty quotations from early scenes, as Lucia remembers how she and her lover met at the fountain in happier days; Lucia, so to speak, embraced her opera. But Lady relinquishes her opera, loses any connectedness to her own previous actions. With her words she helplessly returns to the past, but she can't recall the right tunes any more. Verdi's sleepwalking scene is a study in amnesia: the music illustrates the erasing of Lady's mind, its blanching into a state of silent candour. The text shows that great gaps are opening in Lady's intelligence; the music anticipates the final condition, pure extinction of faculty - 'Out, out, brief candle!' says Macbeth (5.5.23), but his wife is the one holding the taper.

Catatonia is a disease in which a general paralysis occurs because nerve signals are firing too rapidly to transmit feasible commands to muscles: and Verdi's sleepwalking scene is an astonishing exercise in the kinaesthetics of catatonia. The tempo is Largo: the dynamics hover around $p p p$; but we hear continual allusions to fast trembling, thready pulses, aborted nerve-spasms, unscreamed screams. The scene begins in the fatal $\mathrm{F}$ minor of the grand duet 'Fatal mia donna' and so much else in the opera. (The opera has two main harmonic regions, $\mathrm{F}$ and $\mathrm{B}$ flat for the Macbeths, and E for the witches.) The important musical elements in this opening section, a nearly athematic delirium, are these:

(1) a staccato tracery of a slightly altered $\mathrm{F}$ minor scale, anticipated in the first-act prelude - a bit of musical gooseflesh, a sort of petit pas for mice on tiptoe (Ex. 13).

31 Verdi's 'Macbeth', 154. 


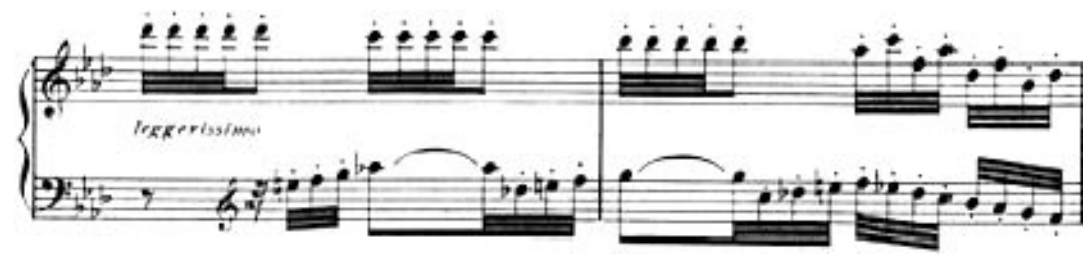

Ex. 13: formication

(2) a double-dotted sway, an important theme in the first-act prelude, accompanied by arpeggios of an $\mathrm{F}$ minor triad and a $\mathrm{C}$ dominant chord, a slow-motion replay of the $\mathrm{i}-\mathrm{V}$ motto - constituent of so many of the opera's epigrams - here Lady seems to be falling into her private rhythm, a humming self-hypnosis, a druggy state of acedia (Ex. 14).

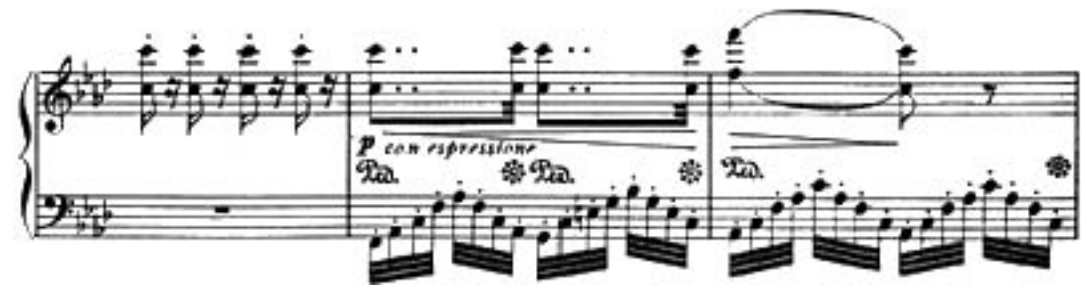

Ex. 14: sway

(3) a reedy chromatic descent, recurring when the doctor notes that she keeps rubbing her hands - this may be one of Verdi's musical equivalents to Lady's single gesture, her vain attempt to wash away the blood; or an anticipation of the death-rattle, for Lady is steeped in death, in the midst of death, throughout this scene (Ex. 15).

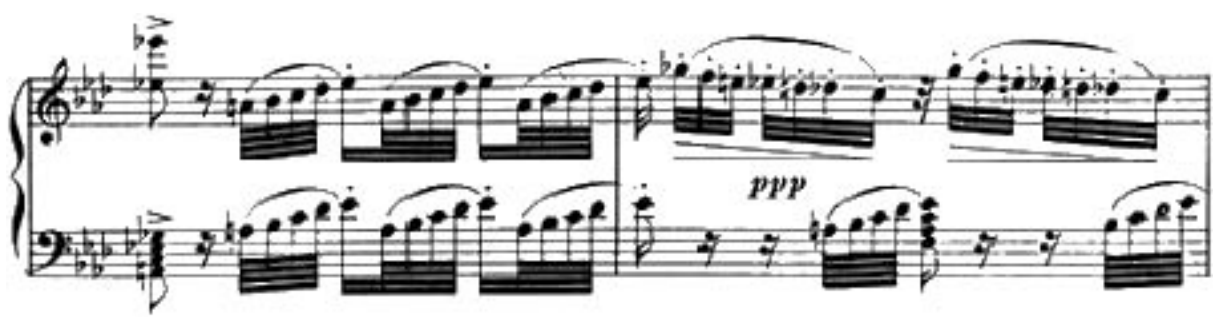

Ex. 15: hand gesture

Hand, voice, faculty of sight, seem to be growing displaced into orchestral gestures. Jane Bernstein, who has closely studied descriptions of the hand movements of actresses playing Shakespeare's Lady Macbeth from Sarah Siddons to Adelaide Ristori, notes that in Verdi's sleepwalking scene 'her hands take on a preternatural life of their own ... [the opera] is centred not on the voice but on the body of the prima donna' - a description that beautifully captures the way in which the 
disintegration of customary melody reflects the disintegration of the body. ${ }^{32}$ King James considered that witches were called sortiari because their practices were determined by lot or chance; and here we see Verdi turning the riddle, generating a scene out of music - bits abutting one another inconsequentially - or, better, with dramatic consequence, not musical.

If the sleepwalking scene isn't a mad scene in the Lucia manner, what is it? The emphasis on gesture and on the singer's physical body, the fragmentary, tessellated quality of the musical discourse, the phantasmal aspect of the action - all point to ballet-pantomime instead of opera. Marian Smith, in her remarkable book Ballet and Opera in the Age of Giselle, shows just how ballet-pantomime composers wrestled their music into shapes that embodied action and psychology; she quotes a number of Parisian critics from the 1830s and 1840s:

Ballet music has a particular character: it is more accented, more parlante, more expressive than opera music, because it is not destined only to accompany and enhance the words of the librettist, but to be itself the entire libretto.

Generally, one does not ask for music from a ballet-pantomime composer, but for an orchestra that is the translation, the commentary of the text that one would not otherwise be able to understand. ${ }^{33}$

A ballet-pantomime score, then, isn't music: it's just a transposition of words and story into wordless sound. If a sylphide flaps her wings, the composer will oblige with a dainty flutter of demisemiquavers. ${ }^{34}$ The disrupted gesticisms of Verdi's sleepwalking scene seem to accord well with such experiments in translating pantomime into music. Smith notices that the old ballet-pantomime is a continual attempt to find surrogates for language: 'composers, choreographers, and designers at the Opéra introduced words into ballet performances in every way but actually having performers intone them' - including on-stage placards and orchestral quotations of familiar tunes whose lyrics were relevant to the action. ${ }^{35}$ The sleepwalking scene is a sort of ballet-pantomime in which the performer does intone words - words that float in a semi-disconnected way above the descriptively intent orchestral discourse. In the 1865 version of Macbeth, the Hecate ballet-pantomime uses some of the same gestic devices (strengthening the link between Lady and the witches), though the basic Hecate music is an infernal waltz, whereas Lady's basic sleepwalk music is a lullaby - perhaps one might even call it a 'Sommeil'.

In the third act of Lully's Atys (1676), there is an eerie scene presided over by the god Morpheus, who sends, first, Phantase to remind the sleeping Atys of the joys of Cybèle's love, and then a dance-chorus of 'Songes funestes' to warn Atys of the terrors that would beset a lover faithless to a goddess. Lully carefully separates the soothing dreams from the nightmare; but Verdi mixes them up, creating an effect

32 Jane Bernstein, " "Bewitched, Bothered and Bewildered": Lady Macbeth, Sleepwalking, and the Demonic in Verdi's Scottish Opera', this journal, 14/1-2 (March 2002), 31-46, here 36 and 45 .

33 Marian Smith, Ballet and Opera in the Age of Giselle (Princeton, 2000), 5-6.

34 Smith, 8.

35 Smith, 97. 
of false, anxious calm. There is a similar effect in Vivaldi's flute concerto 'La notte', RV 439, with its quick transitions between soft, too-heavy breathing ('il sonno') and gasps, thrills ('fantasmi'). A dream world is an eminently suitable locale for a ballet-pantomime - as Gautier noted 'fairyland is the place where the action of a ballet can be most easily developed' - and the music of the sleepwalking scene is a conspectus of sleep. ${ }^{36}$

Barish is right to say that there are no direct quotations, here or elsewhere in the sleepwalking scene, from earlier melodies; but Lady's opening phrase is full of the ghosts of quotations, quotations in the process of effacing themselves, losing salience. In the first two bars of the $\mathrm{D}$ flat major section, we hear, in combination, the falling semitone of the epigram 'Tutto è finito' and the scalar rise and octave drop-off that marks Lady's ambition in several places in the opera, notably (in the 1865 version) Lady's cry of 'È necessario' (from 'La luce langue'). Verdi places great emphasis on the falling semitone by putting the first note in a position where it desperately needs to fall: this figure occupies such positions as Bbb-Ab (scale degrees b 6-5); in some sense the whole scene is simply stating 'tutto è finito', IT'S ALL OVER, in huge letters. When Lady starts to sing, her vocal line doesn't clash with the slow paroxysms in the orchestra, but it doesn't pay much attention to the orchestra either - the heavily emphatic voice, singing the sputtery vagrant line 'Chi poteva in quel vegliardo tanto sangue immaginar?' ('Who would have thought the old man to have had so much blood in him?'), seems disconnected from the accompaniment, disconnected from normal patterns of melodic development, disconnected from itself - a musical equivalent to the involution of Lady's mind, its self-immural in foot-thick walls. She's snatching at a tune that she can't quite find; the witch is self-bewitched, lost in her own labyrinth. Sometimes it feels as if Lady is an extraneous figure in her own scene: the orchestral music provides a stunned accompaniment for a zombie ballet, which Lady helplessly figures with vocal graffiti. The sleepwalking scene offers no abrupt changes in mood - indeed Lady seems to have fallen into some state almost beneath mood, a dead calm; but Verdi has managed to transfer the notion of mad discontinuity to other aspects of his musical discourse, while retaining the sense of a single vast arc of drama. Verdi was one of the first opera composers to note that madness is not pretty.

At last Lady's voice fades out on a cadenza, 'Andiam, Macbetto', as if she were sinking into complete rhythmlessness, her private time outside all clock-time. And the sleepwalking scene ends with the tiptoeing-mouse theme from the beginning, now in D flat, not F minor, as if Verdi were imagining Lady stepping into Lethe, entering the tranquillity of oblivion. If this theme were in F minor, the sleepwalking scene would be a segment of an endless purgatorial loop; but in $\mathrm{D}$ flat we feel that Lady has reached The End.

\section{The End}

The 1865 version of the opera ends with a chorus, 'Macbeth, Macbeth ov'è?' - the headiest, most exultant chorus Verdi was ever to write; rapid, double-dotted,

36 Smith, 67. 


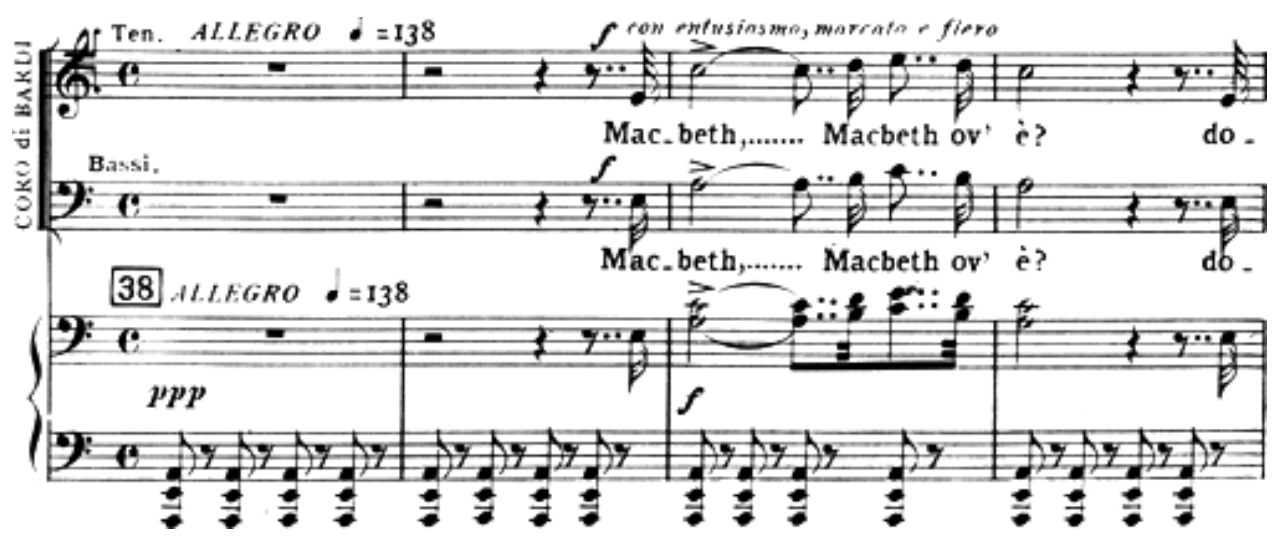

Ex. 16: victory

springy, it has it something of the built-in political activism of Hanns Eisler's marches from the 1930s.

The people of Scotland delight that a thunderbolt from the God of victory has destroyed the usurper; then they honour their new king. If the witches were demons, the play would end with their slinking back, defeated, into hell. But the witches of Macbeth nowhere gnash their teeth or rage at the triumph of justice; in fact their plan succeeds in every last detail, and the army of Macduff and Malcolm is as much an instrument for expediting their wishes as the magic cauldron is. This can be understood, in the orthodox Christian fashion, as the subsumption of partial evils into the universal good; but it can be understood less effortfully as an allegation of something distasteful - petty and deformed - in the action of Providence itself. Teleology colludes with the wilful; the abyss is full of maggots. 